\title{
Modeling indoor TV/screen viewing and adult physical and mental health: Health Survey for England, 2012
}

\author{
Ivy Shiue ${ }^{1,2,3}$
}

Received: 12 May 2015 / Accepted: 25 February 2016 / Published online: 5 March 2016

(C) The Author(s) 2016. This article is published with open access at Springerlink.com

\begin{abstract}
The aim of the present study was to model indoor TV/ screen viewing and a series of adult health conditions and cognitive performance in a country-wide, population-based setting in recent years. Data was retrieved from Health Survey for England, 2012. Information on demographics, lifestyle factors, selfreported health conditions, and TV and/or screen watching hours in adults was collected by household interviews. Chi-square test and survey-weighted logistic and multi-nominal modeling were performed. Of 8114 English adults aged 18-98, 4138 people $(51.1 \%)$ watched TV and/or screen daily for $2 \mathrm{~h}$ or more on average. Two thousand five-hundred people (30.9\%) watched for $3 \mathrm{~h}$ or more. TV and/or screening watching for $2+$ hours was associated with endocrine or metabolic disorders, diabetes, mental disorders (including poor scores in General Health Questionnaire and Warwick-Edinburgh Mental Well-being Scale), nervous system disorders, eye complaints, circulatory system disorders, respiratory system disorders, musculoskeletal system disorders, and self-rated health. TV and/or screen watching for $3+$ hours was associated with digestive disorders and clotting disorder. TV and/or screen watching for $5+$ hours was associated with cancer. TV and/or screen watching for $6+$, $8+$, or $11+$ hours was associated with bladder disease, genitourinary system disorders or bowel disease, respectively. There
\end{abstract}

Responsible editor: Philippe Garrigues

Ivy Shiue

ivy.shiue@northumbria.ac.uk

1 Faculty of Health and Life Sciences, Northumbria University, Newcastle upon Tyne NE1 8ST, England, UK

2 Owens Institute for Behavioral Research, University of Georgia, Athens, GA, USA

3 Alzheimer Scotland Dementia Research Centre, University of Edinburgh, Edinburgh, UK were no risk associations (within $20 \mathrm{~h}$ ) found with ear complaints, infectious disease, and blood system disorders. Future educational and public health programs minimizing TV and/or screen viewing in order to protect from physical inactivity and $\mathrm{X}$ radiation might be needed while research on the combined effect of physical inactivity and X-radiation should be explored.

Keywords Chronic disease $\cdot$ Mental health $\cdot$ Screen · Television · Indoor radiation - Sedentary behavior · Cognitive performance $\cdot$ Self-rated health

\section{Introduction}

\section{Evidence before this study}

Exposure to radiation has been found to increase blood-brain barrier (Nittby et al. 2009), and previous research mostly used regional electromagnetism transmission stations to measure the exposure, which are in the outdoor setting (Sirav and Seyhan 2009; Burch et al. 2006). This has left the knowledge gap in understanding the link of environmental exposure to indoor radiation and human health (Tofani et al. 1985). TV and/or screen viewing might be one of the sources, although likely being chronic rather than acute.

\section{Knowledge gap}

The associations of the duration of TV and/or screen viewing, which could emit X-radiation however low frequency, and chronic health conditions of specific types and/or symptoms in adults and the very old have been less paid attention to, compared to that in children and adolescents. Methodologically, previous studies tended to correlate 2,3 , or $4 \mathrm{~h}$ with health conditions. In other words, effects of longer hours of TV and/or screen watching have not been examined yet. 


\section{Study aim}

Following this context, therefore, the aim of the present study was to model indoor TV/screen viewing and a series of adult health conditions including both physical and mental health using a unique statistical approach in an independent data set in a country-wide and population-based setting in recent years. It was also assumed that the study participants have had constant TV and/or screen viewing patterns over time.

\section{Methods}

\section{Study sample}

As described elsewhere in detail, Health Survey for England (more detail via http://www.hscic.gov.uk/ article/3741/Health-Survey-for-England-Health-socialcare-and-lifestyles) has been a country-wide, populationbased, multi-year study since 1991. It is a major monitoring tool looking at the health of people who have resided in England. It is used by the British Government to plan health services and make important policy decisions that have an impact on its citizens. It includes information on individual physical health, lifestyle behaviors, social care, physical measures, mental health, and wellbeing. Participants are selected using a random probability sample. The survey design ensures that every address in England has an equal chance of being included in the survey each year and the results are representative of the population living in private households (more details via http://www.natcen.ac.uk/ our-research/research/health-survey-for-england/). Data was collected by household interviews. In the current analysis, the most recent study wave in 2012 with the available data on demographics, lifestyle factors, selfreported health conditions, and TV and/or screen watching hours was selected.

\section{Variables and analyses}

In the first step of data analysis, associations between TV and/or screen watching hours ( $x$ variable; Question: How much time did you spend sitting down watching TV, including DVDs and videos?) and a series of selfreported health conditions (y variables) in English adults aged 18-98 were assessed. Health conditions included endocrine or metabolic disorders, diabetes, mental disorders, nervous system disorders, eye complaints, ear complaints, circulatory system disorders, respiratory system disorders, musculoskeletal system disorders, infectious disease, blood system disorders and self-rated health, digestive disorders, clotting disorder, bladder disease, genito-urinary system disorder, or bowel disease (Question: Do you suffer from...?). In the second step, associations between TV and/or screen watching hours and English adult mental health using General Health Questionnaire 12-item (GHQ-12) and The WarwickEdinburgh Mental Well-being Scale (WEMWBS) were examined. Of note, GHQ-12 has been utilized to assess subject's mental health and psychological distress status (Goldberg 1978), and the WEMWBS is a scale of 14 positively worded items, with five response categories, for assessing a population's mental wellbeing (more details via http://www.healthscotland.com/scotlands-health/ population/Measuring-positive-mental-health.aspx). Both of them have been used and validated in many study populations over the last decades (Farmer and Harvey 1975; Clarke et al. 2011).

Covariates including age, sex, body mass index, hypertension, serum cotinine, and physical activity level were adjusted in the modeling. Effects were estimated by using odds ratios (OR) or relative risk ratios (RRR) together with $95 \%$ confidence intervals $(\mathrm{CI})$, depending on the outcome variables being binary or categorical. All the statistical models were weighted for the sampling and survey design. Since the study variable of TV and/or screen watching hours is ordinal, being 1 to $20 \mathrm{~h}$, statistical analyses were executed repeatedly from 1 to $20 \mathrm{~h}$ in order to find out how many hours of TV and/or screen watching could and to what extent increase the risk of different adult chronic health conditions. Statistical software STATA version 13.0 (STATA, College Station, Texas, USA) was used to perform all the statistical analyses. The results were therefore listed in the corresponding tables accordingly. Of note, only statistically significant associations were shown.

\section{Ethics considerations}

Since there were only secondary data analyses employed without any participant personal information identified by extracting statistical data from the study website in the present study, no further ethics approval for conducting the present study was required (more details via http://www. ethicsguidebook.ac.uk/Secondary-analysis-106).

\section{Results}

\section{Descriptive statistics}

Of all the 8114 English adults aged 18-98, 4138 people $(51.1 \%)$ watched TV and/or screen daily for $2 \mathrm{~h}$ or more on average. Two thousand five-hundred people $(30.9 \%)$ watched for $3 \mathrm{~h}$ or more. Seven hundred seventy-one people $(9.5 \%)$ watched for $5 \mathrm{~h}$ or more. Four hundred five people (5.0\%) watched for $6 \mathrm{~h}$ or more. One hundred sixty-two people 
$(2.0 \%)$ watched for $8 \mathrm{~h}$ or more. Sixty-one people $(0.8 \%)$ watched for $11 \mathrm{~h}$ or more.

\section{Analytical statistics}

Table 1 shows associations between TV and/or screen watching hours and self-reported health conditions in English adults. Reporting TV and/or screen watching for $2+$ hours was associated with endocrine or metabolic disorders, diabetes, mental disorders, nervous system disorders, eye complaints, circulatory system disorders, respiratory system disorders, musculoskeletal system disorders, and self-rated health. Reporting TV and/or screen watching for $3+$ hours was associated with digestive disorders and clotting disorder. Reporting TV and/or screen watching for $5+$ hours was associated with cancer while reporting TV and/or screen watching for $6+$, $8+$ or $11+$ hours was associated with bladder disease, genito-urinary system disorders, or bowel disease, respectively.

Tables 2 and 3 present associations between TV and/ or screen watching pattern and English adult mental health by GHQ-12 and WEMWBS, respectively. Reporting watching TV and/or screen for $2 \mathrm{~h}$ or more was associated with poor GHQ-12 scores. Specific symptoms included lost sleep over worry, felt not playing useful part in things, felt incapable of making decisions, felt could not overcome difficulties, unable to enjoy day-to-day activities, been unable to face problems, been feeling unhappy and depressed, been losing confidence in self, been thinking of self as worthless, not feeling optimistic about the future, not feeling useful, not feeling interested in other people, not dealing with problems well, not feeling good about myself, not feeling confident, not able to make up my own mind about things, not interested in new things, and not feeling cheerful. Other symptoms included unable to concentrate, felt constantly under strain, no energy to spare, not feeling relaxed, not thinking clearly, not feeling close to other people, and not feeling loved when people reported watching TV and/or screen for $3 \mathrm{~h}$ or more.

\section{Discussion}

\section{TV and/or screen watching and physical health}

Increased TV watching may be a sign of environmental dependency and therefore leads to loss of personal autonomy such that a person's environment almost entirely controls their actions (Shin et al. 2013). In American black women aged 2169, TV watching was associated with an increased type 2 diabetes risk: The incidence rate ratio was 1.86 (95\% CI
1.54-2.24) for $>=5 \mathrm{~h}$ relative to $<1 \mathrm{~h}$ of television per day, independent of physical activity (Krishnan et al. 2009). Similar results were obtained in American men aged 40-75 (Hu et al. 2001), the relative risks of diabetes across categories of average hours spent watching TV per week $(0-1,2-10,11-$ 20, 21-40, and $>40)$ were $1.00,1.66,1.64,2.16$, and 2.87, respectively $(P$ for trend $<0.001$ ). In English older adults, TV viewing time was associated with incident diabetes mellitus at 2-year follow-up ( $\geq 6 \mathrm{~h} /$ day compared with $<2 \mathrm{~h} /$ day; OR 4.27 , $95 \%$ CI 1.69-10.77), although the association was attenuated to the null in final adjusted models that included body mass index (Smith and Hamer 2014). Compared with those in the lowest quartile, the ORs of the metabolic syndrome in the highest quartile of TV viewing time were 1.42 (95\% CI 0.93-2.15) for Australian men and 1.42 (95 \% CI 1.012.01) for women aged 60 and above (Gardiner et al. 2011). In 10 European countries, adults aged 45-79 were observed to have increased risk of total cardiovascular disease or coronary heart disease in those who had $1 \mathrm{~h}$ or more TV watching per day (Wijndaele et al. 2011). Moreover, TV viewing time was found to be inversely associated with both total body lean mass $(P=0.05)$ and leg lean mass $(P<0.01)$ in Australian adults aged 60-86 (Gianoudis et al. 2014). In a very recent metal-analysis, it was concluded that TV watching time could have increased risks of colon cancer, endometrial cancer, lung cancer but not cancers of the breast, rectum, ovaries, prostate, stomach, esophagus, testes, renal cell, and non-Hodgkin lymphoma (Schmid and Leitzmann 2014). These studies tended to have various measurements and statistical modeling with various sizes of study populations that might need validity checking. Literature on other included physical health conditions was very scarce. Therefore, it was not possible to compare and discuss the implications.

\section{TV and/or screen watching and mental health}

Although the relationship of TV viewing and mental health such as depression might not be uncommon (Teychenne et al. 2010), research focusing on adults is still limited. Previously (Hamer et al. 2010), it was observed that Scottish adults with the highest TV and/or screening watching time level ( $>4 \mathrm{~h} /$ day) had an increase in GHQ-12 score of 0.28 (95\% CI 0.05-0.51), compared with those with the lowest level ( $<$ or $=2 \mathrm{~h} /$ day). In Australian adults aged 25 and above, each 1-h/day increment in TV viewing time was associated with lower physical $(-0.56$ $[95 \%$ CI $-0.77,-0.34])$ and mental $(-0.41[-0.70,-0.12])$ component summary scores and vitality $(-0.51[-0.81$, $-0.21]$ ) using SF-36 questionnaire (Hetsroni 2012). There is also a lack of research looking into how TV and/or screening watching might affect daily cognitive function in adults. For example, previous psychological research observed that love styles could have also been influenced by TV watching and further affect one's emotional and/or behavioral problems 
Table 1 Associations between TV/screen watching duration and common adult health conditions ( $n=8114$; aged 18-98)

\begin{tabular}{|c|c|c|c|c|}
\hline & $<2 \mathrm{~h}(n=3961,48.9 \%)$ & $>=2 \mathrm{~h}(n=4138,51.1 \%)$ & OR $(95 \% \mathrm{CI})^{\mathrm{a}}$ & $P$ value \\
\hline \multicolumn{5}{|c|}{ Endocrine/metabolic } \\
\hline No & $3706(50.8 \%)$ & $3587(49.2 \%)$ & 1.00 & \\
\hline Yes & $251(31.5 \%)$ & $547(68.6 \%)$ & $1.45(1.20-1.76)$ & $<0.001$ \\
\hline \multicolumn{5}{|c|}{ Diabetes } \\
\hline No & $3777(50.6 \%)$ & $3695(49.5 \%)$ & 1.00 & \\
\hline Yes & $183(29.5 \%)$ & $438(70.5 \%)$ & $1.60(1.30-1.98)$ & $<0.001$ \\
\hline \multicolumn{5}{|c|}{ Nervous system } \\
\hline No & $3849(49.5 \%)$ & $3921(50.5 \%)$ & 1.00 & \\
\hline Yes & $108(33.6 \%)$ & $213(66.4 \%)$ & $1.68(1.26-2.24)$ & $<0.001$ \\
\hline \multicolumn{5}{|c|}{ Eye complaints } \\
\hline No & $3892(49.6 \%)$ & $3960(50.4 \%)$ & 1.00 & \\
\hline Yes & $65(27.2 \%)$ & $174(72.8 \%)$ & $1.48(1.06-2.07)$ & 0.021 \\
\hline \multicolumn{5}{|c|}{ Heart/Circulatory system } \\
\hline No & $3651(51.7 \%)$ & $3417(48.3 \%)$ & 1.00 & \\
\hline Yes & $306(29.9 \%)$ & $7171(70.1 \%)$ & $1.39(1.17-1.65)$ & $<0.001$ \\
\hline \multicolumn{5}{|c|}{ Respiratory system } \\
\hline No & $3711(49.7 \%)$ & $3764(50.4 \%)$ & 1.00 & \\
\hline Yes & $246(39.9 \%)$ & $370(60.1 \%)$ & $1.21(1.00-1.46)$ & 0.052 \\
\hline \multicolumn{5}{|c|}{ Musculoskeletal system } \\
\hline No & $3475(52.0 \%)$ & $3205(48.0 \%)$ & 1.00 & \\
\hline \multirow[t]{2}{*}{ Yes } & $482(34.2 \%)$ & $9292(65.8 \%)$ & $1.35(1.17-1.55)$ & $<0.001$ \\
\hline & $<3 \mathrm{~h}(n=5599,69.1 \%)$ & $>=3 \mathrm{~h}(n=2500,30.9 \%)$ & OR $(95 \% \mathrm{CI})^{\mathrm{a}}$ & $P$ value \\
\hline \multicolumn{5}{|c|}{ Mental disorders } \\
\hline No & $5319(69.6 \%)$ & $2319(30.4 \%)$ & 1.00 & \\
\hline Yes & $274(60.5 \%)$ & $179(39.5 \%)$ & $1.63(1.30-2.04)$ & $<0.001$ \\
\hline \multicolumn{5}{|c|}{ Digestive system } \\
\hline No & $5374(69.9 \%)$ & $2320(30.2 \%)$ & 1.00 & \\
\hline Yes & $219(55.2 \%)$ & $178(44.8 \%)$ & $1.42(1.14-1.78)$ & 0.002 \\
\hline \multicolumn{5}{|c|}{ Clotting disorder } \\
\hline No & $3538(66.5 \%)$ & $1628(31.5 \%)$ & 1.00 & \\
\hline \multirow[t]{2}{*}{ Yes } & $63(43.2 \%)$ & $83(56.9 \%)$ & $1.56(1.08-2.25)$ & 0.017 \\
\hline & $<5 \mathrm{~h}(n=7328,90.5 \%)$ & $>=5 \mathrm{~h}(n=771,9.5 \%)$ & OR $(95 \% \mathrm{CI})^{\mathrm{a}}$ & $P$ value \\
\hline \multicolumn{5}{|l|}{ Cancer } \\
\hline No & $7189(90.8 \%)$ & $733(9.3 \%)$ & 1.00 & \\
\hline \multirow[t]{2}{*}{ Yes } & $132(78.1 \%)$ & $37(21.9 \%)$ & $1.63(1.07-2.47)$ & 0.022 \\
\hline & $<6 \mathrm{~h}(n=7694,95.0 \%)$ & $>=6 \mathrm{~h}(n=405,5.0 \%)$ & OR $(95 \% \mathrm{CI})^{\mathrm{a}}$ & $P$ value \\
\hline \multicolumn{5}{|c|}{ Bladder disease } \\
\hline No & $1244(91.9 \%)$ & $110(8.1 \%)$ & 1.00 & \\
\hline \multirow[t]{2}{*}{ Yes } & $361(88.1 \%)$ & $49(12.0 \%)$ & $1.52(1.05-2.19)$ & 0.026 \\
\hline & $<8 \mathrm{~h}(n=7937,98.0 \%)$ & $>=8 \mathrm{~h}(n=162,2.0 \%)$ & OR $(95 \% \mathrm{CI})^{\mathrm{a}}$ & $P$ value \\
\hline \multicolumn{5}{|c|}{ Genito-urinary system } \\
\hline No & $7766(98.1 \%)$ & $153(1.9 \%)$ & 1.00 & \\
\hline \multirow[t]{2}{*}{ Yes } & $164(95.4 \%)$ & $8(4.7 \%)$ & $2.55(1.13-5.79)$ & 0.025 \\
\hline & $<11 \mathrm{~h}(n=8038,99.2 \%)$ & $>=11 \mathrm{~h}(n=61,0.8 \%)$ & OR $(95 \% \mathrm{CI})^{\mathrm{a}}$ & $P$ value \\
\hline \multicolumn{5}{|c|}{ Bowel disease } \\
\hline No & $1622(99.1 \%)$ & $15(0.9 \%)$ & 1.00 & \\
\hline Yes & $128(97.0 \%)$ & $4(3.0 \%)$ & $3.71(1.02-13.45)$ & 0.046 \\
\hline
\end{tabular}

${ }^{a}$ Adjusted for age, sex, body mass index, hypertension, smoking status, indoor second-hand smoking, and physical activity 
Table 2 Associations between daily TV/screen watching and adult mental health by General Health Questionnaire

\begin{tabular}{|c|c|c|c|c|}
\hline & $<2 \mathrm{~h}(n=3961,48.9 \%)$ & $>=2 \mathrm{~h}(n=4138,51.1 \%)$ & $\operatorname{RRR}(95 \% \mathrm{CI})^{\mathrm{a}}$ & $P$ value \\
\hline \multicolumn{5}{|l|}{ Self-rated health } \\
\hline Good to very good & $3247(54.6 \%)$ & $2696(45.4 \%)$ & 1.00 & \\
\hline Fair & $546(35.6 \%)$ & $990(64.5 \%)$ & $1.67(1.47-1.91)$ & $<0.001$ \\
\hline Poor to very poor & $168(27.2 \%)$ & $450(72.8 \%)$ & $2.43(1.96-3.01)$ & $<0.001$ \\
\hline \multicolumn{5}{|l|}{ GHQ-12 } \\
\hline Score 0 & $2169(49.5 \%)$ & $2209(50.5 \%)$ & 1.00 & \\
\hline Score $1-3$ & $841(50.9 \%)$ & $812(49.1 \%)$ & $1.00(0.88-1.14)$ & 0.971 \\
\hline Score $4+$ & $482(45.0 \%)$ & $589(55.0 \%)$ & $1.23(1.07-1.43)$ & 0.005 \\
\hline \multicolumn{5}{|l|}{ Lost sleep over worry } \\
\hline Normal & $2945(49.4 \%)$ & $3012(50.6 \%)$ & 1.00 & \\
\hline More than usual & $604(47.3 \%)$ & $673(52.7 \%)$ & $1.23(1.07-1.42)$ & 0.004 \\
\hline \multicolumn{5}{|c|}{ Felt playing useful part in things } \\
\hline Normal & $3212(50.1 \%)$ & $3197(49.9 \%)$ & 1.00 & \\
\hline Less than usual & $316(40.6 \%)$ & $463(59.4 \%)$ & $1.23(1.07-1.51)$ & 0.007 \\
\hline \multicolumn{5}{|c|}{ Felt capable of making decisions } \\
\hline Normal & $3332(49.7 \%)$ & $3369(50.3 \%)$ & 1.00 & \\
\hline Less than usual & $219(40.9 \%)$ & $317(59.1 \%)$ & $1.28(1.05-1.57)$ & 0.015 \\
\hline \multicolumn{5}{|c|}{ Felt could not overcome difficulties } \\
\hline Normal & $3213(49.7 \%)$ & $3251(50.3 \%)$ & 1.00 & \\
\hline More than usual & $336(44.0 \%)$ & $428(56.0 \%)$ & $1.29(1.09-1.53)$ & 0.003 \\
\hline \multicolumn{5}{|c|}{ Been able to face problems } \\
\hline Normal & $3294(49.9 \%)$ & $3303(50.1 \%)$ & 1.00 & \\
\hline Less than usual & $264(40.2 \%)$ & $393(59.8 \%)$ & $1.38(1.15-1.65)$ & $<0.001$ \\
\hline \multicolumn{5}{|c|}{ Been losing confidence in self } \\
\hline Normal & $3145(50.0 \%)$ & $3151(50.1 \%)$ & 1.00 & \\
\hline More than usual & $411(43.0 \%)$ & $546(57.1 \%)$ & $1.39(1.20-1.62)$ & $<0.001$ \\
\hline \multicolumn{5}{|c|}{ Been thinking of self as worthless } \\
\hline Normal & $3338(49.8 \%)$ & $3372(50.3 \%)$ & 1.00 & \\
\hline More than usual & $216(39.9 \%)$ & $326(60.2 \%)$ & $1.55(1.26-1.90)$ & $<0.001$ \\
\hline \multicolumn{5}{|c|}{ Been feeling reasonably happy } \\
\hline Normal & $3201(49.4 \%)$ & $3275(50.6 \%)$ & 1.00 & \\
\hline \multirow[t]{2}{*}{ Less than usual } & $355(45.8 \%)$ & $420(54.2 \%)$ & $1.19(1.00-1.40)$ & 0.048 \\
\hline & $<3 \mathrm{~h}(n=5599,69.1 \%)$ & $>=3 \mathrm{~h}(n=2500,30.9 \%)$ & OR $(95 \% \mathrm{CI})^{\mathrm{a}}$ & $P$ value \\
\hline \multicolumn{5}{|l|}{ Able to concentrate } \\
\hline Normal & $4496(70.6 \%)$ & $1876(29.4 \%)$ & 1.00 & \\
\hline Less than usual & $533(61.8 \%)$ & $329(38.2 \%)$ & $1.43(1.21-1.68)$ & $<0.001$ \\
\hline \multicolumn{5}{|c|}{ Felt constantly under strain } \\
\hline Normal & $4094(69.8 \%)$ & $1771(30.2 \%)$ & 1.00 & \\
\hline More than usual & $935(68.6 \%)$ & $428(31.4 \%)$ & $1.18(1.02-1.37)$ & 0.023 \\
\hline \multicolumn{5}{|c|}{ Able to enjoy day-to-day activities } \\
\hline Normal & $4355(71.7 \%)$ & $1770(28.9 \%)$ & 1.00 & \\
\hline Less than usual & $688(60.4 \%)$ & $451(39.6 \%)$ & $1.47(1.27-1.70)$ & $<0.001$ \\
\hline \multicolumn{5}{|c|}{ Been feeling unhappy and depressed } \\
\hline Normal & $4326(70.4 \%)$ & $1818(29.6 \%)$ & 1.00 & \\
\hline More than usual & $713(64.4 \%)$ & $394(35.6 \%)$ & $1.37(1.19-1.59)$ & $<0.001$ \\
\hline
\end{tabular}

${ }^{\text {a }}$ Adjusted for age, sex, body mass index, hypertension, smoking status, indoor second-hand smoking, and physical activity

(Hetsroni and Lowenstein 2013). Such situation might give an alarm on future potential criminal and/or victimization behaviors (Dempsey et al. 2014). In the present study, the large quantitative research evidence showed that more TV and/or 
Table 3 Associations between daily TV/screen watching and adult mental health by Warwick-Edinburgh Mental Well-being Scale

\begin{tabular}{|c|c|c|c|c|}
\hline & $<2 \mathrm{~h}(n=3961,48.9 \%)$ & $>=2 \mathrm{~h}(n=4138,51.1 \%)$ & OR $(95 \% \mathrm{CI})^{\mathrm{a}}$ & $P$ value \\
\hline \multicolumn{5}{|c|}{ Been feeling optimistic about the future } \\
\hline Normal & $2203(48.7 \%)$ & $2325(51.4 \%)$ & 1.00 & \\
\hline Less than sometimes & $221(37.7 \%)$ & $366(62.4 \%)$ & $1.37(1.12-1.68)$ & 0.002 \\
\hline \multicolumn{5}{|l|}{ Been feeling useful } \\
\hline Normal & $2282(48.3 \%)$ & $2444(51.7 \%)$ & 1.00 & \\
\hline Less than sometimes & $141(36.1 \%)$ & $250(63.9 \%)$ & $1.50(1.18-1.89)$ & 0.001 \\
\hline \multicolumn{5}{|c|}{ Been feeling interested in other people } \\
\hline Normal & $2265(48.4 \%)$ & $2420(51.7 \%)$ & 1.00 & \\
\hline Less than sometimes & $151(37.4 \%)$ & $253(62.6 \%)$ & $1.56(1.24-1.96)$ & $<0.001$ \\
\hline \multicolumn{5}{|c|}{ Been dealing with problems well } \\
\hline Normal & $2294(47.9 \%)$ & $2492(52.1 \%)$ & 1.00 & \\
\hline Less than sometimes & $132(38.9 \%)$ & $207(61.1 \%)$ & $1.36(1.06-1.74)$ & 0.014 \\
\hline \multicolumn{5}{|c|}{ Been feeling good about myself } \\
\hline Normal & $2230(48.1 \%)$ & $2408(51.9 \%)$ & 1.00 & \\
\hline Less than sometimes & $194(39.6 \%)$ & $296(60.4 \%)$ & $1.43(1.14-1.79)$ & 0.002 \\
\hline \multicolumn{5}{|l|}{ Been feeling confident } \\
\hline Normal & $2236(48.2 \%)$ & $2403(51.8 \%)$ & 1.00 & \\
\hline Less than sometimes & $187(39.1 \%)$ & $291(60.9 \%)$ & $1.49(1.20-1.86)$ & $<0.001$ \\
\hline \multicolumn{5}{|c|}{ Been able to make up my own mind about things } \\
\hline Normal & $2348(47.6 \%)$ & $2587(52.4 \%)$ & 1.00 & \\
\hline More than sometimes & $79(39.5 \%)$ & $121(60.5 \%)$ & $1.42(1.03-1.97)$ & 0.033 \\
\hline \multicolumn{5}{|c|}{ Been interested in new things } \\
\hline Normal & $2266(48.5 \%)$ & $2411(51.6 \%)$ & 1.00 & \\
\hline More than sometimes & $167(35.8 \%)$ & $300(64.2 \%)$ & $1.53(1.22-1.92)$ & $<0.001$ \\
\hline \multicolumn{5}{|l|}{ Been feeling cheerful } \\
\hline Normal & $2297(47.5 \%)$ & $2537(52.5 \%)$ & 1.00 & \\
\hline \multirow[t]{2}{*}{ More than sometimes } & $134(43.2 \%)$ & $176(56.8 \%)$ & $1.42(1.10-1.83)$ & 0.007 \\
\hline & $<3 \mathrm{~h}(n=5599,69.1 \%)$ & $>=3 \mathrm{~h}(n=2500,30.9 \%)$ & OR $(95 \% \mathrm{CI})^{\mathrm{a}}$ & $P$ value \\
\hline \multicolumn{5}{|l|}{ I have had energy to spare } \\
\hline Normal & $2746(71.2 \%)$ & $1109(28.8 \%)$ & 1.00 & \\
\hline Less than sometimes & $748(59.2 \%)$ & $516(40.8 \%)$ & $1.49(1.29-1.71)$ & $<0.001$ \\
\hline \multicolumn{5}{|l|}{ Been feeling relaxed } \\
\hline Normal & $3104(69.0 \%)$ & $1395(31.0 \%)$ & 1.00 & \\
\hline Less than sometimes & $375(63.1 \%)$ & $219(36.9 \%)$ & $1.54(1.26-1.90)$ & $<0.001$ \\
\hline \multicolumn{5}{|l|}{ Been thinking clearly } \\
\hline Normal & $3372(68.7 \%)$ & $1535(31.3 \%)$ & 1.00 & \\
\hline Less than sometimes & $128(56.9 \%)$ & $97(43.1 \%)$ & $1.75(1.28-2.39)$ & $<0.001$ \\
\hline \multicolumn{5}{|c|}{ Been feeling close to other people } \\
\hline Normal & $3269(68.8 \%)$ & $1482(31.2 \%)$ & 1.00 & \\
\hline \multirow[t]{2}{*}{ Less than sometimes } & $219(60.3 \%)$ & $144(39.7 \%)$ & $1.63(1.26-2.12)$ & $<0.001$ \\
\hline & $<4 \mathrm{~h}(n=6721,83.0 \%)$ & $>=4 \mathrm{~h}(n=1378,17.1 \%)$ & OR $(95 \% \mathrm{CI})^{\mathrm{a}}$ & $P$ value \\
\hline \multicolumn{5}{|l|}{ Been feeling loved } \\
\hline Normal & $4109(83.2 \%)$ & $809(16.8 \%)$ & 1.00 & \\
\hline Less than sometimes & $205(70.7 \%)$ & $85(29.3 \%)$ & $1.97(1.46-2.66)$ & $<0.001$ \\
\hline
\end{tabular}

${ }^{\text {a }}$ Adjusted for age, sex, body mass index, hypertension, smoking status, indoor second-hand smoking, and physical activity

screening (more than $3 \mathrm{~h}$ ) was related to less feeling of being loved in addition to unhappiness and other negative thoughts. This could come with the less clear thinking and close relationship with others as co-effects, as shown in the results. 


\section{X-radiation exposure in the household}

If we believe that in every English household the X-radiation is limited to the standard as required starting from the end of 2012 (more details via http://en.wikipedia.org/wiki/ Analogue_terrestrial_television_in_the_United Kingdom\#405_line_system), the exposure per day shall be between $45 \mathrm{Megahertz}(\mathrm{MHz})$ and $847.25 \mathrm{MHz}$. If we assume that on average in every English household the wavelength from using TV is $446.125 \mathrm{MHz}$ per hour, by using the formula $(45+847.25) / 2$, this could mean that roughly the English adults were exposed to 446.125 to $8922.5 \mathrm{MHz}(1-20 \mathrm{~h})$ per day, although distance to $\mathrm{TV} / \mathrm{screen}$ might need to be included in the equation as well. Likely, they could have started to develop health problems when it reached $892.25 \mathrm{MHz}$ and above ( $2+$ hours). However, this estimation has excluded the time on the use of other technology with screens that could also emit varying degrees of X-radiation.

\section{Strengths and limitations}

The present study has a few strengths. Firstly, it lied in its very large and representative study sample, being country-wide and population-based, and in recent years. Secondly, it was also the first time to model how TV and/or screen watching hours were correlated with different adult chronic health conditions in England. Thirdly, the study variable of TV and/or screen watching was not binary, being yes or no, but ordinal by presenting in hours. Therefore, it was available to examine how many hours of TV and/or screen watching (up to $20 \mathrm{~h}$ ) could be linked with different chronic health conditions.

However, there are also a few limitations that cannot be ignored. First, it was unable to include all the subtypes of each health condition and the objective measurement of TV and/or screening viewing due to the limitation of the current dataset. Second, it was also unable to examine if and how engaging with indoor exercise during TV and/or screen watching intervals might help lessen the risk effect on human health and well-being (Mekary et al. 2013). Third, the causality cannot be established due to the cross-sectional study design in nature. There might be reverse causation bias that was unavoidable. Specifically, whether TV and/or screen viewing habits and patterns could have changed after certain health events (this could be one-time point or continuous) was unknown. For example, it was recently observed that people with mental disorders (e.g., dysthymia, panic disorder, and agoraphobia) could have spent more time viewing TV than people without (de Wit et al. 2011). Fourth, health conditions were only selfreported in the survey but not cross-checked with hospital admissions by physician diagnosis. Therefore, there might be some underestimates or overestimates in the disease prevalence. Still, there could be diagnosis or classification bias in hospital admissions resulting in diagnosis avoidance or over- diagnosis (Burgard and Chen 2014; Eggers et al. 2009; Minasian et al. 2013). Taken together, future studies keeping the strengths and overcoming the limitations mentioned above in a longitudinal or experimental approach to confirm or refute the current findings would be recommended.

\section{Research, practice, and policy implications}

In sum, over half of English adults viewed TV and/or screen for 2+ hours daily while almost one-third English adults viewed TV and/or screen daily for $3+$ hours daily. TV and/or screening viewing for $2+$ hours was observed to be associated with endocrine or metabolic disorders, diabetes, mental disorders, nervous system disorders, eye complaints, circulatory system disorders, respiratory system disorders, musculoskeletal system disorders, and self-rated health. TV and/or screen viewing for $3+$ hours was found to be associated with digestive disorders and clotting disorder. Moreover, TV and/or screen viewing for $5+$ hours was associated with cancer and $\mathrm{TV}$ and/or screen viewing for $6+, 8+$, or $11+$ hours was associated with bladder disease, genito-urinary system disorders, or bowel disease, respectively.

Too much TV and/or screen viewing is harmful to both physical and mental health. Recent research has also observed the potential risk effect on DNA damage in children (Himmetoglu et al. 2015). For future research, a longitudinal or experimental approach to confirm or refute the current findings while examining the role of TV/screening viewing in any illness recovery and/or family relationship to form the healthy and balanced lifestyle would be suggested. In addition, examination on the accumulation of indoor X-radiation in the household over time in addition to the outdoor radiation around the household to fully understand the long-term health effects for occupants should be considered. For clinical practice and policy, future educational, public health, and nursing programs minimizing TV and/or screen viewing alongside regulation on $\mathrm{X}$-radiation at $<=0.5$ milliroentgen per hour (Luketina 1975) in order to protect, sustain, and then optimize human health might need to be encouraged (Hietanen and Hoikkala 1990; Setter et al. 1969).

Acknowledgment None.

Compliance with ethical standards

Conflict of interest None.

Open Access This article is distributed under the terms of the Creative Commons Attribution 4.0 International License (http:// creativecommons.org/licenses/by/4.0/), which permits unrestricted use, distribution, and reproduction in any medium, provided you give appropriate credit to the original author(s) and the source, provide a link to the Creative Commons license, and indicate if changes were made. 


\section{References}

Burch JB, Clark M, Yost MG, Fitzpatrick CT, Bachand AM, Ramaprasad J, Reif JS (2006) Radio frequency nonionizing radiation in a community exposed to radio and television broadcasting. Environ Health Perspect 114:248-253

Burgard SA, Chen PV (2014) Challenges of health measurement in studies of health disparities. Soc Sci Med 106:143-150

Clarke A, Friede T, Putz R, Ashdown J, Martin S, Blake A, Adi Y, Parkinson J, Flynn P, Platt S, Stewart-Brown S (2011) WarwickEdinburgh Mental Well-being Scale (WEMWBS): validated for teenage school students in England and Scotland. A mixed methods assessment. BMC Public Health 11:487

de Wit L, van Straten A, Lamers F, Cuijpers P, Penninx B (2011) Are sedentary television watching and computer use behaviors associated with anxiety and depressive disorders? Psychiatry Res 186:239-243

Dempsey PC, Howard BJ, Lynch BM, Owen N, Dunstan DW (2014) Associations of television viewing time with adults' well-being and vitality. Prev Med 69C:69-74

Eggers KM, Lind L, Venge P, Lindahl B (2009) Will the universal definition of myocardial infarction criteria result in an overdiagnosis of myocardial infarction? Am J Cardiol 103:588-591

Farmer RD, Harvey PG (1975) Minor psychiatric disturbance in young adults. The use of the general health questionnaire in the estimation of the prevalence of non-psychotic disturbance in different groups. Soc Sci Med 9:469-474

Gardiner PA, Healy GN, Eakin EG, Clark BK, Dunstan DW, Shaw JE, Zimmet PZ, Owen N (2011) Associations between television viewing time and overall sitting time with the metabolic syndrome in older men and women: the Australian Diabetes, Obesity and Lifestyle study. J Am Geriatr Soc 59:788-796

Gianoudis J, Bailey CA, Daly RM (2014) Associations between sedentary behaviour and body composition, muscle function and sarcopenia in community-dwelling older adults. Osteoporos Int. doi:10.1007/s00198-014-2895-y

Goldberg DP (1978) Manual of the general health questionnaire. Nfer

Hamer M, Stamatakis E, Mishra GD (2010) Television- and screen-based activity and mental well-being in adults. Am J Prev Med 38:375-380

Hetsroni A (2012) Associations between television viewing and love styles: an interpretation using cultivation theory. Psychol Rep 110:35-50

Hetsroni A, Lowenstein H (2013) Cultivation and counter cultivation: does religiosity shape the relationship between television viewing and estimates of crime prevalence and assessment of victimization likelihood? Psychol Rep 112:303-324

Hietanen MT, Hoikkala MJ (1990) Ultraviolet radiation and blue light from photofloods in television studios and theaters. Health Phys 59: 193-198
Himmetoglu S, Guven MF, Bilsel N, Dincer Y (2015) DNA damage in children with scoliosis following X-ray exposure. Minerva Pediatr 67:245-249

Hu FB, Leitzmann MF, Stampfer MJ, Colditz GA, Willett WC, Rimm EB (2001) Physical activity and television watching in relation to risk for type 2 diabetes mellitus in men. Arch Intern Med 161:1542-1548

Krishnan S, Rosenberg L, Palmer JR (2009) Physical activity and television watching in relation to risk of type 2 diabetes: the Black Women's Health Study. Am J Epidemiol 169:428-434

Luketina IA (1975) X-ray emmissions from colour television receivers in New Zealand. N Z Med J 81:197-200

Mekary RA, Lucas M, Pan A, Okereke OI, Willett WC, Hu FB, Ding EL (2013) Isotemporal substitution analysis for physical activity, television watching, and risk of depression. Am J Epidemiol 178:474-483

Minasian AG, van den Elshout FJ, Dekhuijzen PN, Vos PJ, Willems FF, van den Bergh PJ, Heijdra YF (2013) COPD in chronic heart failure: less common than previously thought? Heart Lung 42:365-371

Nittby H, Brun A, Eberhardt J, Malmgren L, Persson BR, Salford LG (2009) Increased blood-brain barrier permeability in mammalian brain 7 days after exposure to the radiation from a GSM-900 mobile phone. Pathophysiology 16:103-112

Schmid D, Leitzmann MF (2014) Television viewing and time spent sedentary in relation to cancer risk: a meta-analysis. J Natl Cancer Inst 106. doi: 10.1093/jnci/dju098

Setter LR, Snavely DR, Solem DL, Van Wye RF (1969) Regulations, standards, and guides for microwaves, ultraviolet radiation, and radiation from lasers and television receivers - an annotated bibliography. Environ Health Ser Radiol Health 35:1-77

Shin JS, Kim MS, Kim NS, Kim GH, Seo SW, Kim EJ, Heilman KM, Na DL (2013) Excessive TV watching in patients with frontotemporal dementia. Neurocase 19:489-496

Sirav B, Seyhan N (2009) Radio frequency radiation (RFR) from TV and radio transmitters at a pilot region in Turkey. Radiat Prot Dosim 136: $114-117$

Smith L, Hamer M (2014) Television viewing time and risk of incident diabetes mellitus: the English Longitudinal Study of Ageing. Diabet Med 31:1572-1576

Teychenne M, Ball K, Salmon J (2010) Sedentary behavior and depression among adults: a review. Int J Behav Med 17:246-254

Tofani S, Ossola P, Agnesod G (1985) Analysis of environmental pollution by radiofrequency radiation from teleradiocommunication devices. Health Phys 48:475-484

Wijndaele K, Brage S, Besson H, Khaw KT, Sharp SJ, Luben R, Bhaniani A, Wareham NJ, Ekelund U (2011) Television viewing and incident cardiovascular disease: prospective associations and mediation analysis in the EPIC Norfolk Study. PLoS One 6:e20058 